\title{
IN SITU ANALYSIS OF THE CARRIER LIFETIME IN SILICON DURING IMPLANTATION OF 1.5 MeV PROTONS
}

\author{
E. Gaubas国, T. Čeponis 目, A. Uleckas目, J. Vaitkus 目, K. Žilinskas包, V. Kovalevskij \\ M. Gaspariūnas $\mathrm{b}$, and V. Remeikis $\mathrm{b}$ \\ ${ }^{a}$ Vilnius University, Institute of Applied Research, Sauletekio 9, LT-10222 Vilnius, Lithuania \\ E-mail: eugenijus.gaubas@ $\mathrm{ff} . v u .1 \mathrm{t}$ \\ ${ }^{\mathrm{b}}$ State Research Institute Center for Physical Sciences and Technology, Savanoriu 231, LT-02300 Vilnius, Lithuania
}

Received 4 October 2010; revised 23 November 2010; accepted 15 December 2010

\begin{abstract}
The carrier lifetime in situ variations during $1.5 \mathrm{MeV}$ proton irradiation generated by the tandem-type accelerator have been examined in silicon wafer samples. The nonlinear decrease of the carrier lifetime has been obtained within the proton projectile penetration depth, while the effective carrier decay lifetime in the bulk of a silicon wafer decreases slightly. The separation methodology of the surface and bulk recombination parameters is presented. Technology of control of the surface modifications by proton implantation is discussed.
\end{abstract}

Keywords: carrier lifetime, in situ monitoring, proton implantation

PACS: 61.72.Ji, 61.82.Fk, 72.40.+w

\section{Introduction}

Ion implantation is a common technology to modify properties of material and device structures [13] as well as to introduce fast recombination centres [4]. However, the creation of detrimental defects is inevitable when radiation technologies are exploited. Therefore, in situ control of defect introduction and their evolution during implantation of different ions is important for development of the radiation technologies in micro- and nano-electronics. A contactless technique based on measurements of microwave probed photoconductivity transients (MW-PCDT) for the in situ control of evolution of radiation defects within the bulk of silicon structures has been demonstrated [5] for the case of the homogeneous irradiation by penetrative $6-8 \mathrm{MeV}$ protons. The separation of surface and bulk recombination parameters, as the most sensitive characteristic for the defect density and structure, becomes a more complicated measurement problem when thin surface layers are modified by protons of a rather low energy. In situ analysis of the proton irradiation-modified layers is a tool to emulate generation of additional radiation defects during implantation of heavier elements.

In this work, the technology for the in situ control of surface and bulk carrier recombination lifetime has been approbated for silicon wafers during surface modification by $1.5 \mathrm{MeV}$ protons.

\section{Arrangement of experiments and samples}

The high resistivity Si wafers of $300 \mu \mathrm{m}$ thickness, containing the passivating $\mathrm{SiO}_{2}$ layers on both surfaces, were investigated. Surface passivation ensures a rather long effective carrier decay lifetime $\left(\tau_{\text {eff }} \geq 120 \mu \mathrm{s}\right)$ with the surface recombination velocity $s \leq 200 \mathrm{~cm} / \mathrm{s}$. Wafer fragments of dimensions of about $1 \times 2 \mathrm{~cm}^{2}$ were installed on a cold finger within the irradiation chamber.

A sketch of the experimental set-up and the irradiation chamber is shown in Fig. 1.

Implantation of protons has been performed by using the Tandetron 4110A ion accelerator [6] installed at the State Research Institute Center for Physical Sciences and Technology, Vilnius. The acceleration voltage of the latter can be enhanced up to $1.2 \mathrm{MV}$, thus, accelerated hydrogen ions can reach the energy up to 2.4 MeV.

A special irradiation chamber has been designed and fabricated for these experiments. The cold finger with the embedded sample is attached to a bottom chamber, the position of which can be adjusted by using the bellows system and actuators. The top component of the 


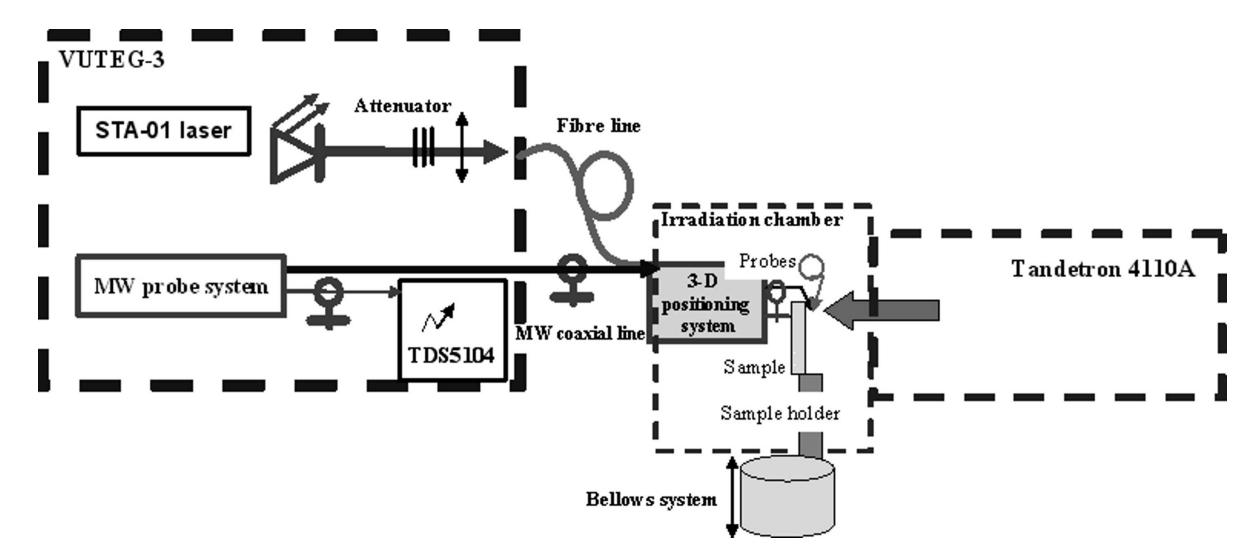

Fig. 1. Sketch of the experimental set-up. The main components are: instrument VUTEG-3 for excitation/probe of the MW-PCD transients, the irradiation chamber supplied with actuators, and the accelerator Tandetron 4110A.

irradiation chamber is similar to that described in [5]. The only modification is made by locating the fibremicrowave antennas onto the front-surface of the wafer under irradiation. Also, excitation wavelength of either 531 or $1062 \mathrm{~nm}$ is employed alternately to separate the carrier decay rate within the proton projectile length and for the evaluation of the $\tau_{\text {eff }}$ parameter, respectively. The single mode fibres have been used for transfer of either 531 or $1062 \mathrm{~nm}$ excitation laser pulses to a sample in vacuum.

The oblique excitation geometry, relative to the sample face-surface and to the proton beam, has been implemented to avoid shadowing of the irradiation spot within the examined sample area by the excitation - microwave probe tips. A CsI plate is exploited to visualize the proton beam for the initial adjustment of intersection of the fibre-microwave antennas and a centre of the irradiation beam. The beam of the diameter of $6 \mathrm{~mm}$ has been collimated onto the sample position.

The beam current was changed in steps from 0.4 to $20 \mathrm{nA}$ in order to measure more precisely the carrier lifetime variations during exposure. The proton flux is measured by using a Faraday-cup sensor installed within a beam transfer vacuumated $\left(<10^{-6}\right.$ torr $)$ tube. Valves within the tubes also provide a possibility to manipulate access of protons to the sample under investigation. The irradiation exposure duration is measured by the computer clocked in with the irradiation episodes. The averaged transient (of about 100 decays) is measured every second and controlled by PC.

The MW-PCD signal is collected by a coaxial needletip antenna averaging the excess carrier density variations within the output fibre-tip spot of dimensions of several micrometres. The excitation pulses of the $100 \mathrm{~Hz}$ repetition rate and of duration of $400 \mathrm{ps}$ are generated by the STA- 01 micro-chip laser. The main $(1062 \mathrm{~nm})$ and second harmonic $(531 \mathrm{~nm})$ light gener- ated by this laser and KTP crystal, respectively, is filtered by spectral filters and collimated onto fibre input. Intensity of excitation pulses is varied by neutral filters placed within the trace of the laser beam. The proton beam induced density of $\mathrm{e}-\mathrm{h}$ pairs has been additionally controlled by measuring the total leakage current in a reversely biased Si diode. However, the proton irradiation induced rates of the steady-state excess carrier generation $<10^{6} \mathrm{~cm}^{-3} \mathrm{~s}^{-1}$ do not approach the carrier excitation rate obtained by the short laser pulses (of the order of $>10^{24} \mathrm{~cm}^{-3} \mathrm{~s}^{-1}$ ), exploited in the photo-excitation of the MW-PCD signals.

\section{Variations of recombination parameters}

The projectile depth of the $1.5 \mathrm{MeV}$ protons within $300 \mu \mathrm{m}$ thick Si wafers comprises about $30 \mu$ m nearby the front-surface of the sample under investigation. This irradiation profile (Fig. 2) has been simulated by using the Transport of Recoils and Ions in Matter (TRIM) Monte Carlo simulation program [7]. It can be seen in Fig. 2(c) that the radiation modified layer contains a pedestal and a peak of the vacancy-type defect production at about $10 \%$ of the wafer depth. Vacancy associated defects are usually the dominant defects which modify carrier recombination/generation characteristics in silicon [4, 8]. This complicates measurements of carrier recombination characteristics when the layered structure is actually formed during implantation of protons.

Therefore, a combined methodology has been applied to control both the in situ and post-irradiation states of the defect system and its evolution:

(i) a near-surface layer of the effective depth $d_{\text {eff }}=$ $\alpha^{-1}+D t_{\text {tr }}$ has been in situ controlled during a set $(m)$ exposure (of duration $t_{\text {exp }, m-\text { epis }}$ ) episodes by 

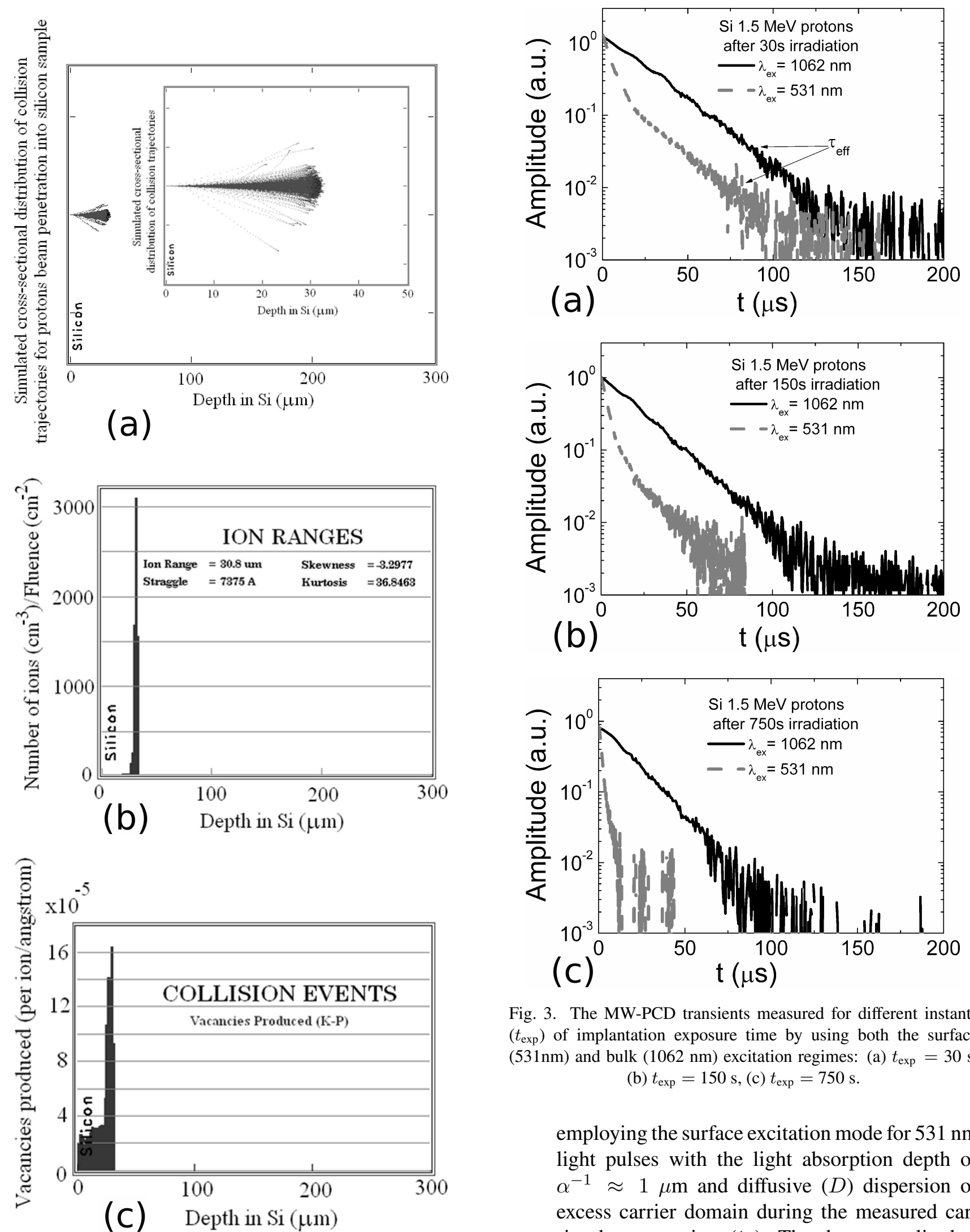

Fig. 3. The MW-PCD transients measured for different instants $\left(t_{\exp }\right)$ of implantation exposure time by using both the surface $(531 \mathrm{~nm})$ and bulk $(1062 \mathrm{~nm})$ excitation regimes: (a) $t_{\exp }=30 \mathrm{~s}$, (b) $t_{\exp }=150 \mathrm{~s}$, (c) $t_{\exp }=750 \mathrm{~s}$.

employing the surface excitation mode for $531 \mathrm{~nm}$ light pulses with the light absorption depth of $\alpha^{-1} \approx 1 \mu \mathrm{m}$ and diffusive $(D)$ dispersion of excess carrier domain during the measured carrier decay transient $\left(t_{\mathrm{tr}}\right)$. The shape, amplitudes, and carrier decay rates within this MW-PCD transient exhibit changes in a product of capture crosssection $(\sigma)$ and density $(N)$ of radiation-induced

Fig. 2. (a) Cross-sectional distribution of proton collisions, (b) projectile range for $1.5 \mathrm{MeV}$ proton implantation into $300 \mu \mathrm{m}$ thick Si wafers, and (c) vacancy-type defect generation, simulated by TRIM. 
recombination centres $\left(\left.\tau\right|_{R s} \sim 1 /(\sigma N)\right)$, when the carrier decay lifetime becomes shorter than that of higher surface recombination modes determined carrier density relaxation [9]. The shorter decay transient, the more precise control of $\tau_{R s}$ is achieved;

(ii) before irradiation and within the range (of $m-$ 1 and $m$ th) of the adjacent irradiation episodes the effective decay lifetime at bulk excitation (1062 nm light pulses) is rapidly measured to separate the bulk carrier lifetime (if any distant damage appears) and either the surface recombination velocity or the inherent lifetime (caused by radiation damage) within a front layer;

(iii) cross-sectional scans within the wafer depth have been performed after irradiations by using the perpendicular (relative to irradiation direction) profiling of the carrier lifetime [9, 10]. This profile shows the final carrier recombination lifetime depth-distribution within the implanted wafer.

The initial irradiation episodes have been kept rather short to measure the exposure characteristic more precisely. Also, the beam current was kept low during these initial irradiation episodes. Changes of decay transients for different instants within the exposure time are illustrated in Fig. 3. These transients had been registered till significant changes were observable, and then the beam current had been increased and irradiation exposure continued. It can be noticed that transients obtained for the surface excitation regime are two-component, and amplitude of the asymptotic constituent decreases rapidly with the exposure duration. Eventually, the asymptotic constituent disappears (for $t_{\exp }=750 \mathrm{~s}$, Fig. 3(c)), while initial constituent of a transient becomes significantly shorter than that of the decay rate (compare with Fig. 3(a)) determined by the higher surface recombination decay modes [9-11]. This result implies the formation of a two-layered structure during implantation: the asymptotic amplitude qualitatively indicates the rate of surface recombination of a single-layered structure [9, 10], while transformation (Fig. 4) of a transient to a single exponential decay shows that the bulk recombination within the front implanted layer prevails. Then, non-irradiated bulk of the wafer outside the proton projectile range shows rather slow reduction of the effective carrier lifetime (due to shrinkage of thickness of the undamaged material and enhanced recombination at its front surface) for the homogeneous bulk excitation regime at $1062 \mathrm{~nm}$ wavelength.

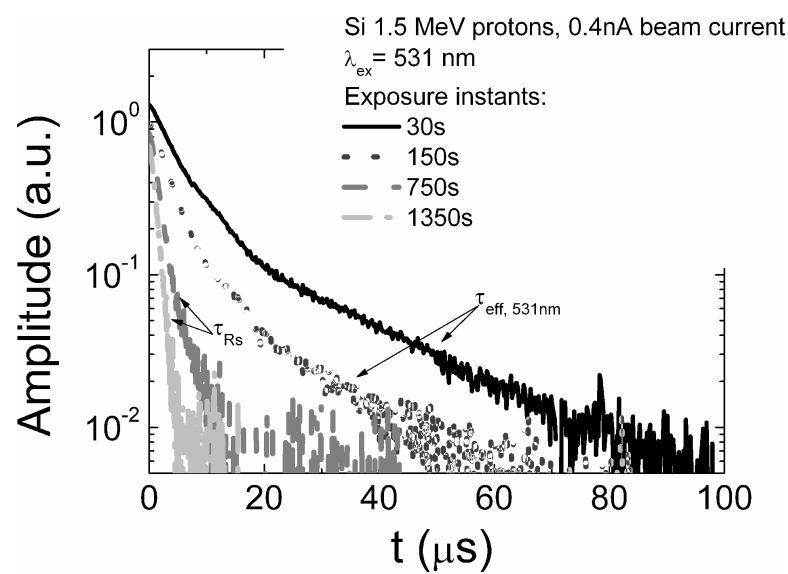

Fig. 4. Evolution of the MW-PCD transients with implantation exposure time for the surface excitation regime.

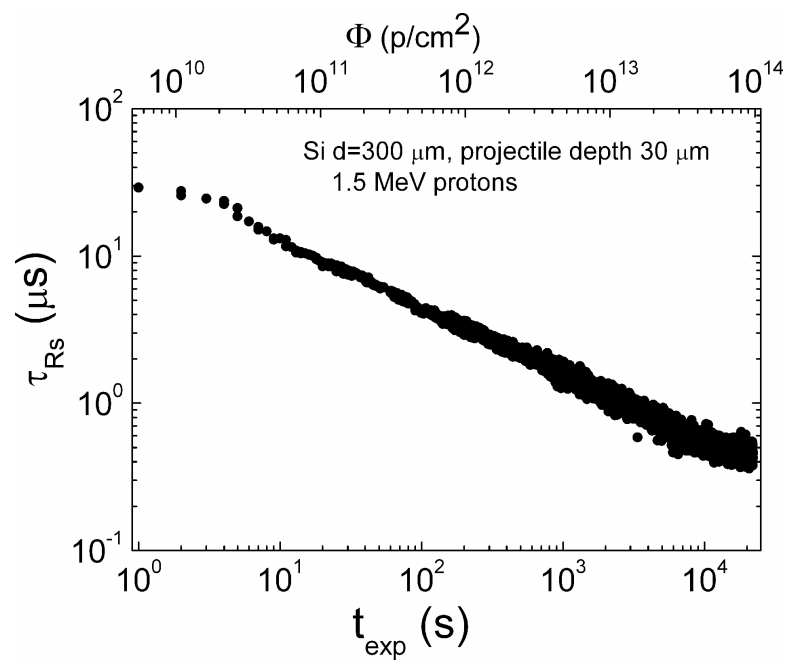

Fig. 5. Carrier decay lifetime extracted from MW-PCD transients for surface excitation regime as a function of both the exposure time (bottom scale) and $1.5 \mathrm{MeV}$ proton fluence (top scale).

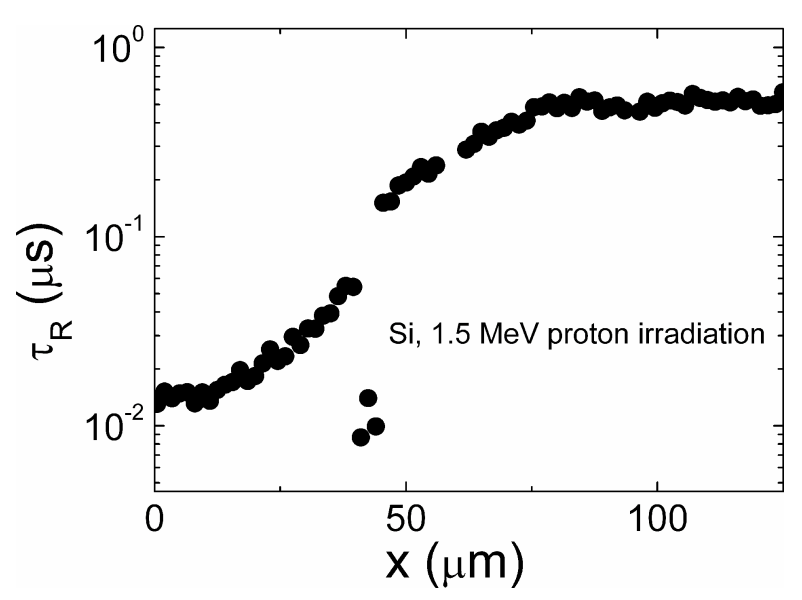

Fig. 6. Carrier decay lifetime $\tau_{R s}$ profile within a Si wafer crosssectional boundary measured after $1.5 \mathrm{MeV}$ proton implantation. 
The carrier recombination lifetime $\tau_{R s}$ extracted from the initial decay component measured for the surface excitation regime, as a function of both the irradiation exposure time $t_{\exp }$ and the proton fluence $\Phi$, is illustrated in Fig. 5. It can be seen that slower reduction of $\tau_{R s}$ with enhancement of irradiation fluence is obtained within initial exposure episodes $\left(t_{\exp }<10 \mathrm{~s}\right)$. The slow reduction of $\tau_{R s}$ can be explained by the insufficient precision for the separation between the carrier decay instant lifetime, due to the higher surface recombination modes, and the bulk lifetime within the thin implantation modified layer during primary irradiation stages. The sub-linear reduction of $\tau_{R s} \sim \Phi^{-\frac{1}{2}}$ has been obtained as a function of fluence $\Phi$ enhancement within a wide range $\left(t_{\exp }=10-20000 \mathrm{~s}\right)$ of exposure times.

The latter fluence-dependent $\tau_{R s} \sim \Phi^{-\frac{1}{2}}$, which actually averages recombination lifetime variations within the proton projectile range, can be qualitatively explained by variation of density of radiation defects. The increase of the radiation defect density determines a reduction of distances $\left(l_{\mathrm{d}}\right)$ among the defects. Due to a sharp recombination boundary for the projectile range (Fig. 2) of protons and beam-induced lateral inhomogeneity of defect density, carriers experience twodirectional gradients within the implanted layer. Then, the proportionality relations are derived: $\tau_{R s} \sim \frac{1}{N} \sim$ $l_{\mathrm{d}}^{2} \sim \Phi^{-\frac{1}{2}}$, under assumption that the introduction rate of the dominant defects varies linearly with fluence. Probably, the absolute values of $\tau_{R s}$ represent the material depth-averaged characteristic within irradiation pedestal when the material damage contains a $\delta$-shape rather narrow peak (Fig. 2) at the proton stopping depth $R$. Therefore, the cross-sectional scan of the carrier lifetime depth-distribution has been performed after irradiation (Fig. 6).

The cross-sectional scan of the carrier lifetime depthdistribution was carried out by generating the excess carriers with strongly absorbed light $(531 \mathrm{~nm})$ pulses to avoid the deep initial penetration of excitation light. Then, the lateral and depth diffusive dispersion of the domain of excess carriers can be roughly neglected, within the first iteration of decay transient analysis. Hereby, the evaluated carrier decay lifetime $\tau_{R s}$ as a function of depth coordinate $x$ within the wafer sample (along wafer thickness direction) boundary is plotted in Fig. 6. The shortest $\tau_{R s}$ values are obtained at the front surface of the implanted wafer and at $R$. These values are close or even shorter than those measured during irradiation. This result hints at the slight transformation/activation of the radiation-induced re- combination centres in post-irradiation sustention. On the other hand, the depth averaged values of $\tau_{R s}$ are recorded when using the oblique measurement geometry (in situ), while these $\tau_{R s}$ values indicate density of recombination centres within a layer of several micrometer width (spot of the single mode fibre) within the cross-sectional profiling experiments. Really, lateral diffusion of carriers is inevitable, within the second iteration of the analysis. This might be a reason for an enhancement of the measured $\tau_{R s}$ values within its profile for the probe location nearby the proton projectile depth - carrier diffusion towards/from adjacent layers located close to the most densely damaged layer $(R)$ location. Actually, the narrow range of the shortest carrier decay lifetimes $\tau_{R s}$ is observed at the expected position of $R \geq 30 \mu \mathrm{m}$ within $\tau_{R s}(x)$ profile. The discrepancy between the simulated and measured $R$ position can be explained by the experimental errors $\Delta$ due to the fibre spot diameter $(\phi \approx 6 \mu \mathrm{m})$ and the defect peak dispersion (width of $\delta$-layer at half of its peak amplitude is $\delta \approx 10 \mu \mathrm{m}$, Fig. 2(c)), while a step within positioning of probes comprises $2.5 \mu \mathrm{m}$ with the precision not worse than $1 \mu \mathrm{m}$. Thus, the maximal positioning error value is $\Delta \approx 16 \mu \mathrm{m}$. Thereby, the obtained position of $x_{0}$ for a drop of $\tau_{R s}(x)$ within its profile (Fig. 6) can be estimated as being in agreement with the simulated $x_{0}=R+\Delta$ one. Values of $\tau_{R s}(x)$ are enhanced relative to those at the front surface, and stabilized far outside $R$, being rather constant across the non-irradiated material. Decrease of the absolute values of $\tau_{R s}$ within non-irradiated material (relative to those measured in the oblique geometry at the passivated surface, Figs. 3,4) is caused by non-passivated boundary of the wafer, while their depth-distribution correctly represents the $\tau_{R s}(x)$ profile. These profiling results corroborate the fluence-dependent variations of $\tau_{R s}$ measured in situ.

\section{Summary}

The applied methodology of the in situ analysis of recombination parameters during implantation of $1.5 \mathrm{MeV}$ protons enabled us to control the generation of radiation defects and evolution of their density with fluence. The sub-linear decrease of the carrier recombination lifetime $\tau_{R s} \sim \Phi^{-\frac{1}{2}}$ as a function of fluence has been revealed. Peculiarities of this irradiation characteristic are explained by the formation of a twolayered structure of the implanted silicon wafer. The obtained position of $x_{0}$ for a drop of $\tau_{R s}(x)$ within its depth-profile is in agreement with simulated $x_{0}=R$ 
including correlation and measurement errors caused by fixed dimensions of probes and by dispersion of defect density at half-amplitude of its peak. Values of $\tau_{R s}(x)$ are enhanced relative to those at the front surface, and stabilized far outside $R$, being rather constant across the layer of the non-irradiated material. The presented technique for the in situ control of implantation procedure is a promising tool in the technology of the precise formation of thin surface layers of the enhanced recombination rate and for predicting the generation of the inevitable satellite radiation defects during implantation of heavier ions.

\section{Acknowledgements}

This work has been implemented under bilateral collaboration agreement between the Institute of Applied Research, Vilnius University and the State Research Institute Center for Physical Sciences and Technology, Vilnius. Dr. A. Plukis is acknowledged for fruitful discussions in design of experiments. J. Kusakovskij and K. Birzul are appreciated for assistance in measurements. The Vilnius University part of this work was supported by the Lithuanian Research Council grant Nr. TAK-10001.

\section{References}

[1] V. Kozlovski and V. Abrosimova, Radiation Defect Engineering (World Scientific Publishing Co., Singapore, 2005).
[2] C. Claeys and E. Simoen, Radiation Effects in Advanced Semiconductor Materials and Devices (Springer, Berlin, 2002)

[3] M. Nastasi and J.V. Mayer, Ion Implantation and Synthesis of Materials (Springer, Berlin, 2006).

[4] E. Gaubas, T. Čeponis, A. Uleckas, J. Vaitkus, and J. Raisanen, Recombination characteristics in $2-3 \mathrm{MeV}$ protons irradiated FZ Si, Nucl. Instrum. Methods A 612, 559-562 (2010).

[5] E. Gaubas, A. Uleckas, J. Vaitkus, J. Raisanen, and P. Tikkanen, Instrumentation for the in situ control of carrier recombination characteristics during irradiation by protons, Rev. Sci. Instrum. 81, 053303 (2010).

[6] M. Gaspari?nas, G. Gervinskas, V. Kovalevskii, R. Plukienè, Š. Vaitekonis, V.V. Levenets, and A. Plukis, Proton and ion microbeam collimation for irradiation of biological samples in air, Lithuanian J. Phys. 50, 363-368 (2010).

[7] http://www.srim.org/.

[8] M. Huhtinen, Simulation of non-ionising energy loss and defect formation in silicon, Nucl. Instrum. Methods A 491, 194 (2002).

[9] E. Gaubas, Transient absorption techniques for investigation of recombination properties in semiconductor materials, Lithuanian J. Phys. 43, 145-165 (2003).

[10] E. Gaubas, J. Vaitkus, E. Simoen, C. Claeys, and J. Vanhellemont, Excess carrier cross-sectional technique for determination of the surface recombination velocity, Mater. Sci. Semicond. Processing 4, 125-131 (2001).

[11] E. Gaubas and J. Vanhellemont, A simple technique for the separation of bulk and surface recombination parameters in silicon, J. Appl. Phys. 80, 6293-6297 (1996). 


\title{
KRŪVININKŲ GYVAVIMO TRUKMĖS TYRIMAS 1,5 MeV PROTONŲ IMPLANTAVIMO İ SILICI
} METU

\author{
E. Gaubas ${ }^{\text {a }}$, T. Čeponis ${ }^{\text {a }}$, A. Uleckas ${ }^{\text {a }}$, J. Vaitkus ${ }^{a}$, K. Žilinskas ${ }^{\text {a }}$, V. Kovalevskij ${ }^{\text {b }}$, M. Gaspariūnas ${ }^{\text {b }}$, \\ V. Remeikis ${ }^{b}$ \\ ${ }^{a}$ Vilniaus universitetas, Taikomuju mokslu institutas, Vilnius, Lietuva \\ ${ }^{\mathrm{b}}$ Valstybinis moksliniu tyrimu institutas Fiziniu ir technologijos mokslu centras, Vilnius, Lietuva
}

\section{Santrauka}

Tirti krūvininkų gyvavimo trukmès kitimai Si plokštelèse 1,5 MeV protonu implantacijos metu, siekiant atskleisti radiacinių defektų evoliucijos ir paviršinių sluoksnių rekombinacijos parametrų technologinès modifikacijos aukštų energijų spinduliuote režimus. Apšvita aukštos energijos protonais vykdyta tandeminio tipo dalelių greitintuvu Tandetron 4110A, veikiančiu Fizinių ir technologijos mokslų centre Vilniuje. Rekombinacijos parametrai ivertinti mikrobangomis zonduojamų fotolaidumo kinetikų metodu, naudojant Vilniaus universitete sukonstruotą ir pagamintą matuokli VUTEG-3. Šiems tyrimams pagaminta lanksti aukšto vakuumo apšvitos kamera. Tokia kamera leido mikrometriniu tikslumu pozicionuoti mikrobangų-šviesolaidinių zondų bei protonų pluoštelio sankirtą. Tirtos krūvininkų tankio relaksacijos kinetikos po sužadinimo trumpu (400 ps) šviesos impulsu kombinuojant paviršinio ir viena- lyčio tūrinio sužadinimo režimus bei keičiant sužadinimo šviesos bangos ilgius. Tokiu būdu išskirti paviršinès rekombinacijos bei rekombinacijos implantuotame sluoksnyje parametrai. Nustatyta, kad krūvininkų rekombinacijos trukmė apšvitintame sluoksnyje trumpejja subtiesiškai implantacijos metu, didejjant apšvitos trukmei ir itėkiui. Tai galima paaiškinti radiacinių defektų sudarymo spartos tiesiškumu bei tarpdefektiniu atstumu mažejimu, didejjant ịtèkiui. Manoma, kad spinduliuotės prasiskverbimo gylyje (protonų visiško sustabdymo siekio skalejje) defektų tankio profilio pjedestalas nulemia šio sluoksnio storyje suvidurkintos krūvininku rekombinacijos trukmès verčių kitimus. Todèl sparčios rekombinacijos labai plonų paviršinių sluoksnių formavimo technologijoje būtina panaudoti papildomas slopinančias plèveles. Tai patvirtina krūvininku gyvavimo trukmès žvalgos profiliai, išmatuoti apšvitintos $\mathrm{Si}$ plokštelès skerspjūvyje. 